\title{
Ways of keeping love alive: Roland Barthes, George du Maurier, and Gilles Deleuze
}

\author{
Heta Pyrhönen \\ Institute for Art Research, Faculty of Arts, University of Helsinki \\ P.O. Box 35 (Fabianinkatu 33), 00014, Helsinki, \\ Finlande-mail: heta.pyrhonen@helsinki.fi
}

\begin{abstract}
The article examines Barthes's A Lover's Discourse (1977) in conjunction with du Maurier's Trilby (1894) in order to present an argument about the similarities they share with the male masochistic fantasy as theorised by Deleuze in his Coldness and Cruelty (1989). Barthes's insistence on the connection between art and love directs my approach. Trilby deals with love and aesthetics in the contexts of art, music, and narrative. The discourses of Trilby's competing lovers over the same woman serve as a point of comparison against which I read Barthes's dramatisation of a lover's discourse. I argue that Barthes's lover shares a number of central discursive figures with the Deleuzian masochistic lover. I examine Barthes's suggestion about the tension between the non-narrative discourse of love and the metalanguage of conventional love stories. I focus on those figures in a lover's discourse that Barthes identifies as keeping this discourse from turning into a love story. My argument is that many of these figures are among the hallmarks of the masochistic fantasy. In particular the formula of disavowal safeguards the lover's discourse, hindering it from turning into a conventional narrative about love.
\end{abstract}

Roland Barthes explains that he wrote Fragments d'un discours amoureux (1977; A Lover's Discourse [1978]) by simulating the action of primary language, the language of love. He purposefully avoids providing a metalanguage of love; instead, his aim is to paint a structural portrait of the discursive site of love. This is the site of an amorous 'I' speaking within himself, confronting the silent love 
object. Such a discursive site includes solely figures, that is, scenes of language showing the lover at work (Barthes 1978: 3). A Lover's Discourse consists of a sample of what Barthes calls the thesaurus of figures, or fragments of discourse expressing things that have been read, heard, and felt about love. Barthes explains that a figure is established once a lover can say: "That's so true! I recognize that scene of language" (Barthes 1978: 4). He further clarifies that the figures enable the lover to make sense of what "befalls" him; however, as they occur to him in a random order, they do not organise his experience as a narrative. Barthes structures his discussion of these figures alphabetically in order to underline their non-syntagmatic and non-narrative nature (Barthes 1978: 6-7). This emphasis suggests that a metalanguage begins to work once a lover's discourse is narrativised. It thus appears as if the discourse Barthes dramatises were inherently hostile to love stories. Although he does not specify what he means by love stories, they seem to designate conventional narratives organised in accordance with the so-called classical model such as Balzac's Sarrasine that Barthes analyses in $S / Z$ (1970). Consequently, he appears to start from the premise that a conventional love story, in its emphasis on sequence, causality, and organisation with a beginning, middle, and an end, already provides the first metalanguage of the lover's discourse.

A Lover's Discourse is Barthes' most popular book, a fact partly explained by its perennially topical subject. Steven Ungar (1983: 117119) emphasises the uniqueness of this book, for while it addresses problems of analysis and interpretation familiar from traditional concerns of literary critics, it does so in a wholly new manner. It is part and parcel of Barthes's search for "another semiotics" that is not tied to structuralism. Instead of an analysis based on metalanguage, Ungar observes, Barthes sees the affirmation of love as his goal. "To look for no more than the affirmation of love," Ungar writes, "is then not at all a simple task when that affirmation calls for an attention whose rigor and sensitivity are none other than those of critical reading" (Ungar 1983: 118). The plethora of literary and critical texts on which Barthes draws in demonstrating how a lover's discourse functions suggests that any examination of this discourse must be placed in contexts allowing love to speak for itself. Literature and the arts in general are pivotal to this discourse, because, claims Barthes, any lover is always an artist. 
Barthes's insistence on the connection between art and love directs my approach, for I juxtapose $A$ Lover's Discourse with a novel about love, George du Maurier's best-seller, Trilby (1894). What makes Trilby a suitable reference point for Barthes's book is that it centres on the notion of the lover as an artist by exploring pictorial art, music, and fiction in relation to love. Trilby is a Künstlerroman focusing on the artistic development of two men, the painter Little Billee and the musician Svengali. Both love the same woman, Trilby, and both regard her as indispensable material for their creative work. A third man, a nameless artist-novelist, narrates this triangular love story. Trilby thus deals with love and aesthetic creation in the contexts of art, music, and narrative fiction. The rivalry of the painter and the musician over Trilby demonstrates their differences as lovers. In anticipation, I show that Little Billee's discourse as a lover adheres to what Gilles Deleuze (1989) calls the masochistic fantasy, in which the male lover and the female love object mutually agree that he submit himself to her. In contrast, Svengali's discourse is that of the demon lover bent on destroying the love object. The distinct discourses of Trilby's two competing lovers serve as a useful point of comparison against which I read Barthes's dramatisation of a lover's discourse. More specifically, I argue that Barthes's lover shares a number of central discursive figures with the Deleuzian masochistic lover. The similarities and differences between the discourses of these lovers form the first focal point of my essay.

My essay's second focal point is grounded in Barthes's suggestion about the hostile tension between the non-narrative discourse of love and the metalanguage of conventional love stories. Once a lover's discourse starts turning into a love story, maintains Barthes, the end of this discourse looms. The lover actually encounters pressure to shift from discourse to conventional narrative, thanks to the "scandalous" nature of love: in its sentimentality, it defies the humdrum nature of daily life (Barthes 1978: 175-179). In his own words, "The love story [...] is the tribute the lover must pay to the world in order to be reconciled to it" (Barthes 1978: 7).

In the following pages I focus on those specific figures in a lover's discourse that Barthes identifies as keeping this discourse from turning into a familiar love story. My argument is that many of these figures are among the typical hallmarks of the masochistic fantasy as formulated by Deleuze in his Coldness and Cruelty (1989). This is to 
say that by exploring the workings of a lover's discourse Barthes is actually illustrating many - although certainly not all — of the basic tenets of the masochistic fantasy. I maintain that these shared connections rest on one formula in particular that Barthes mentions repeatedly: "I know full well, but nevertheless [...]" (Barthes 1978: $22,62,132,177)$. As I subsequently show, this is the formula of disavowal that I then link to Barthes's observations about waiting and suspense as typical figures of a lover's discourse. It is this formula that safeguards the lover's discourse, hindering it from turning into a conventional narrative about love. As it happens, the figures associated with it are among the characteristics that build up the Deleuzian masochistic fantasy.

Finally, I consider the tension Barthes perceives between discourses and narratives about love. In this context, the fate of love plays a great role: does the end of an affair always terminate a lover's discourse? What motivates my examination is that with A Lover's Discourse Barthes encourages us to pay attention to the particular ways in which lovers talk, write, and read, while at the same time promoting the study of the various discursive and narrative strategies with whose help we not only deal with this perennially fascinating subject but also give it form.

At the time of its publication, Trilby was immensely popular, but since it is probably unknown to most present-day readers, I will briefly recall its plot line: Trilby deals with an artists' community in Paris in the 1850s. The plot evolves around the triangle formed by the English painter Little Billee, a German-Jewish musician Svengali, and Trilby O'Ferrall, a nude model for various artists. Little Billee falls in love with Trilby; pleased by his love, Trilby stops modelling. After Trilby finally consents to his proposal of marriage, Little Billee's mother arrives on the scene, demanding that the engagement be called off. Trilby then vanishes from Paris, and Little Billee has a mental breakdown. Personal setbacks, including severe headaches, make Trilby seek help from Svengali who had previously eased her pain by mesmerising her. Aware of Trilby's powerful voice, but her complete tone-deafness, Svengali uses mesmerism in order to turn Trilby into an instrument for his musical ambitions. After rigorous training, Trilby starts performing to international audiences, causing a sensation wherever she goes. She and Svengali then re-encounter Little Billee. The meeting makes Svengali take revenge on both, for he is 
embittered that Trilby has never ceased loving Little Billee. During a performance in London, he does not mesmerise Trilby, and she sings out-of-tune. While the shocked audience is protesting, Svengali suddenly dies. Trilby goes mad, wasting away her last months in Little Billee's care. Soon after Trilby's death, Little Billee dies too. Only the narrator remains to recount the story of his former acquaintances.

\section{In the throes of ravishment}

Ravishment, to quote Barthes, is the "supposedly initial episode [...] during which the amorous subject is 'ravished' [...] by the image of the loved object" (Barthes 1978: 188). In more familiar terms, the figures dealing with ravishment dramatise the lover's falling in love. When Trilby first meets Little Billee, she unwittingly touches the springs of his artistic sensibility by displaying her bare foot. He is "bewildered to find that a real, bare, live human foot could be such a charming object to look at" (du Maurier 1998: 15). Little Billee associates Trilby's foot with "Olympian dignity" (du Maurier 1998: 15) and angels (du Maurier 1998: 20), that is, with classical Antiquity and the sublime. Ravishment affects the lover's discourse, because it causes a reversal in subject-object relationships. It is the loved object that overwhelms the loving subject, not the other way round. The lover is thus subjected to the loved one. Barthes's cautious phrasing — "supposedly initial episode" — shows, however, how difficult it is to characterise a lover's discourse without recourse to the narrative terms familiar from love stories that typically assign love a particular starting point.

The lover's ravishment begins with his sudden experience of a fascinating image such as the line of the shoulders, the slenderness of a silhouette, or the form of a foot (Barthes 1978: 191; see also 20, 71). Barthes links such an enchanting image with what Jacques Lacan calls le petit objet a (Fink 1997: 52), which appears to accommodate exactly a lover's desire, although the lover knows nothing of it consciously. This object is the unsymbolisable remnant of the lover's symbiotic relationship with his first caretaker, usually the mother. The lover experiences the encounter with this object as personal fulfilment, as the conduit back to the lost union he once supposedly enjoyed with the mother. Given that ravishment, evoked by le petit objet $a$, springs 
from the lover's earliest experience of love might explain Barthes's reluctance to assign love's discourse a definitive starting point. If this interpretation is correct, then this discourse cannot, in fact, have a nameable beginning, because the lover has been surrounded by love in the arms of his mother from time immemorial. Moreover, what serves as le petit objet $a$ for one lover does not function in this role for another: "I cannot classify the other," writes Barthes, "for the other is, precisely, Unique, the singular Image which has miraculously come to correspond to the specialty of my desire" (Barthes 1978: 34). No discourse or narrative can fully characterise this special object, a fact that further accounts for the difficulty of fitting the experience of love to any ready-made schemes.

Little Billee is dazzled by his first meeting with Trilby. Her beautiful bare foot inspires him to sketch it on the studio wall. He paints it from memory, and this painted foot, the novel's narrator maintains, "was still to him as the thing itself - an absolute reality" (du Maurier 1998: 24). In keeping with Barthes's argument, Little Billee's ravishment with Trilby takes place after the fact; that is, he does not fall in love with her when he sees her foot, but when he sketches this foot on the wall. Obviously, the foot is a fetish for Little Billee; and, indeed, Barthes conflates le petit objet $a$ with a fetish. In psychoanalytic theory, fetishes are any objects that refer to the childhood fantasy of the mother as having a phallus. The lover's fetishes are paradoxical in nature: although they focus on a bodily part, they nevertheless represent that part as a whole, as everything. This fascinating wholeness makes language falter, because it fits the lover's desire perfectly, making him exclaim, "That's it! That's it exactly (which I love)!" (Barthes 1978: 20). This exclamation is all he can say of the love object. Thanks to the failure of language in the face of such perfection, the lover's discourse cannot but imitate the fragmentary nature of various bodily fetishes. Thus, the hostility this discourse shows towards conventional love stories seems to be based on the fact that this discourse is moored in fetishes.

Barthes grounds the lover's discourse in the lover's experience of a fetish that defies language. Such a basis in turn suggests that the fetish serves as a gateway to another order of reality. In fact, Barthes maintains that a lover's discourse does not derive from this world, but originates in a hallucinatory kind of image repertoire transporting the lover to another realm (Barthes 1978: 28, 99, 107, 127-128). We can 
begin to probe this other realm with the help of the narrator's rhapsody in Trilby on the foot as an amorous fetish. The narrator explains the effect that the sudden sight of Trilby's foot has on Little Billee in the following fashion:

[W]hen Mother Nature has taken extra pains in the building of [a foot] [...] the sudden sight of it, uncovered, comes as a very rare and singularly pleasing surprise to the eye that has learned how to see! Nothing else that Mother Nature has to show, not even the human face divine, has more subtle power to suggest high physical distinction, happy evolution, and supreme development; the lordship of man over beast, the lordship of man over man, the lordship of woman over all! (du Maurier 1998: 16)

Little Billee thinks Mother Nature provides the substance of art. He also associates this substance with his own mother. Trilby, his new love object, has a special way of looking at him. The narrator describes this look in the following fashion: "and in a waking dream Little Billee would remember that his mother had often looked at him like that when he was a small boy, and she a beautiful young woman" (du Maurier 1998: 65; see also 175). At the novel's end Trilby declares that she loves Little Billee just like his mother does (du Maurier 1998: 269). This notion of love enabling the lover to rediscover the lost union with the mother reverberates throughout A Lover's Discourse. Speaking of Goethe's Werther, Barthes describes this union in these words: "nothing but the two of us [...] Werther forms for himself a child's body in which phallus and mother are united, with nothing left over" (Barthes 1978: 128). Little Billee's ravishment with Trilby demonstrates how the lover's sense of such a union dominates the first phases of love during which he ecstatically explores the perfection of the loved being. The seeming correspondence of the fetish with the lover's desire produces this experience of the love object's flawlessness (Barthes 1978: 197). Simultaneously, a trajectory emerges within this discourse: a fetish enables the lover to re-experience the symbiosis of the lost maternal union, which in turn makes available to the lover what Barthes designates as another realm. This is the space of the image repertoire both feeding the lover's discourse and keeping it alive.

In discussing the figures of falling in love, Barthes identifies two features as particularly weighty: the lover's fetishisation of the love object's body and the return to the maternal union. In fact, Carol 
Mavor (2007: 139) claims that the Barthesian lover's discourse is wholly grounded in what she suggestively calls motherotic, the eroticisation of the mother. Taken together, these two features suggest that the love object associated with the mother lacks nothing symbolically. Little Billee's actions as a lover even imply that Trilby's fetishised body generates the symbolism through which he expresses himself. After having sketched Trilby's foot, Little Billee develops in leaps and bounds as an artist. Under the auspices of this fetish he starts finding his own individual style.

When we begin to tie these observations of the lover's discourse to the masochistic fantasy, the first thing to notice is that the fetish plays the same role in both: it serves as a conduit back to the lost maternal union. A further uniting characteristic is the notion that this union then makes available the realm of the imagination. What is more, the fetish associated with the mother appears to generate the symbolism in terms of which both the Barthesian lover and the Deleuzian masochist expresses themselves (Deleuze 1989: 63). It thus seems that whatever similarities there are between these two types of lovers, they are grounded in the roles played by the fetish and the mother. I next explore these features in more detail.

\section{"I know full well but nevertheless..."}

The lover keeps his discourse alive only by preventing it from turning into a love story, which would foresee the end of this discourse. Barthes says that keeping love's discourse afloat requires that the lover protect the image repertoire feeding love. But how does the lover accomplish this task? Barthes suggests two tactics to this end: disavowal and a balance between what he calls the 'two embraces'. I discuss them in this order.

Barthes argues that the lover's persistent affirmation of love in the face of all disparaging efforts to depreciate, limit, erase, and demystify it is encapsulated in the phrase: "I know, I know, but all the same [...]" (Barthes 1978: 22). This is the basic formula, but it takes other forms, too, such as "I have no hope, but all the same" (Barthes 1978: 62); "I know perfectly well [...] but all the same" (Barthes 1978: 132133); and "it's stupid [...] and yet ... it's true" (Barthes 1978: 177). 
Now, as Deleuze points out, this is the formula of disavowal, one that invariably emerges with the fetish. The fetishist - and both the Barthesian lover and the Deleuzian masochist is always one - uses it in order to deny the fact that the mother does not have the phallus. In effect, he says, "I know the mother doesn't have the phallus, but all the same I believe it's hidden somewhere about her; what is more, I have this fetish as proof of its hidden existence" (Fink 1997: 184185). Such disavowal opens up a fantasy space in reality's stead. It means that the fetishist knows how things stand in reality, but chooses to disregard this knowledge in favour of fantasy. His aim is to secure an ideal that is suspended in fantasy. In Deleuze's words, this type of disavowal consists in "radically contesting the validity of that which is: [disavowal] suspends belief in and neutralizes the given in such a way that a new horizon opens up beyond the given and in place of it" (Deleuze 1989: 31). For Barthes in A Lover's Discourse, this fantasy realm is the space of the image repertoire and of the imagination; similarly, for Little Billee in Trilby, it is the space from which all the arts spring. Deleuze even claims that the disavowal typical of the masochistic fantasy is "nothing less than the foundation of imagination, which suspends reality and establishes the ideal in the suspended world" (Deleuze 1989: 128). Thus, for Deleuze masochism is primarily an art of fantasy (Deleuze 1989: 72). I want to suggest that the fetish serves the same function in the Barthesian lover's discourse as it does in the Deleuzian masochistic fantasy: in both it enables the lover to access an imaginary realm of fantasy. In turn, it is this space that safeguards each lover's discourse — but whether these discourses tally point-for-point with one another remains to be seen.

This intimate link among disavowal, the imagination, and fantasy helps to explain why Barthes characterises the lover as an artist. The reason is that the space opened up by disavowal involves sublimation. Suzanne Stewart (1998: 43) explains that "[a]n instinct is sublimated when its aim has been redirected and when its object has been replaced by a socially valued (nonsexual) one." While associating love with sublimation is certainly familiar from many contexts (for example, aesthetic and religious discourses), it does raise questions about the role genital sexuality plays in a lover's discourse. Trilby illustrates how disavowal feeds fantasy, enabling the enamoured artist to sublimate his instincts. That only Little Billee knows how to look at Trilby's foot sets him apart from his artist friends, accounting for his 
superiority over them. Only his "girlish purity of mind" (du Maurier 1998: 9) and his "quick, prehensile, aesthetic eye" (du Maurier 1998: 15) can perceive that the foot functions as a conduit to a higher order of reality. Little Billee seizes on this unexpected sight in order to disavow reality. His artistic gift is based on this connection between disavowal and sublimation, exhibiting a trajectory that moves from the fetish through disavowal to the opening up of a fantasy space in reality's stead.

Little Billee's reaction on unexpectedly encountering the nude Trilby in a studio specifies further the role sublimation plays in his discourse as a lover. Trilby models in the same full-frontal position in which the painter Ingres's painting La Source portrays a woman. Little Billee explains his stupefaction: 'I saw her, I tell you! The sight of her was like a blow between the eyes, and I bolted!' (du Maurier 1998: 80); the narrator says that "as soon as [Little Billee] caught sight of [Trilby] he stopped and stood as one petrified, his shoulder up, his eyes staring" (du Maurier 1998: 82). Nudity as such is not at issue "nothing is so chaste as nudity" (du Maurier 1998: 67) remarks the narrator — but rather Little Billee's sudden confrontation with a display of sexual difference. A woman's nudity in art does not speak of sexual difference, but of sublimation: in the narrator's words, "[t]he more perfect [a woman's] unveiled beauty, the more it appeals to [the artist's] higher instincts"; also, "[a]1l beauty is sexless in the eyes of the artist at his work" (du Maurier 1998: 67). But for Little Billee, sublimation necessitates the existence of one veiled woman, whose phallic quality comes into view as through a curtain. As we have seen, Little Billee associates such a woman, the necessary basis of his art, with his mother. What this means is that he could never have sexual intercourse with Trilby, because it would destroy both his love and his art.

Little Billee's discourse as a masochistic lover and an artist cannot accommodate sexual intercourse, but does such a danger threaten the Barthesian lover's discourse? Barthes actually identifies intercourse as an unfavourable element to this discourse, because having sex, he claims, sends the image repertoire to the devil (Barthes 1978: 104). What Barthes calls the two embraces are relevant in this context. The protection of the lover's fantasy space takes place in discourse, specifically, in talk and speech. These, in turn, are grounded in suspension and waiting. Here is how Barthes describes the lover's 
speech: "To speak amorously is to expend without an end in sight, without a crisis; it is to practice a relation without orgasm" (Barthes 1978: 73). Further, Barthes refers to what he calls the "voluptuous infantilism of sleepiness" (Barthes 1978: 104) that takes place when lovers cradle one another. In this drowsy state they speak to each other. This intimate chatting marks a return to the mother, and here is what Barthes has to say about it: "In this companionable incest, everything is suspended: time, law, prohibition: nothing is exhausted, nothing is wanted: all desires are abolished, for they seem definitively fulfilled" (Barthes 1978: 104). This companionable incest seems to share similarities with the masochistic fantasy in which the lover ostensibly pines after intercourse, but actually wants obstacles and detours in his way towards fulfilment. It seems that in both types of lover's discourse, pleasure is generated by suspension and endless waiting, the purpose of which is to protect the union with the mother. In Mavor's (2007: 157) phrasing, "Barthes prefers a state of sustained illusion, with both his mother and his lovers". Katherine Kolb's examination of the sexual politics of Barthes's $S / Z$ lends further support to my argument. She maintains that in his analysis, Barthes adheres to Balzac's nineteenth-century view of artists as lovers, according to which "sexuality is a loss and a danger for men of action and thinkers and above all artists, who must conserve sexual energy for the sake of artistic potency" (Kolb 2005: 1571).

A closer look at Barthes's two embraces elucidates further the role played by intercourse in the Barthesian lover's discourse. In describing the companionable cuddle of intimate talk, Barthes makes the following observation:

Yet within this infantile embrace, the genital unfailingly appears; it cuts off the diffuse sensuality of the incestuous embrace; the logic of desire begins to function, the will-to-possess returns, the adult is superimposed upon the child. I am then two subjects at once: I want maternity and genitality. (Barthes 1978: 104-105)

The Barthesian lover's discourse is characterised by a pendulum movement swinging back and forth between idealisation grounded in disavowal and the actual sexual relationship. The moment of fullest fulfilment, however, takes place during the incestuous, but non-genital embrace - and this notion pervades the masochistic fantasy as well. 
There is a crucial difference, however, between the Barthesian lover's discourse and the masochistic fantasy: the lover's discourse accommodates the sexual relationship, while the masochistic fantasy rejects genital sexuality altogether. After Trilby finally agrees to marry him, Little Billee writes about the planned marriage to his mother (du Maurier 1998: 226), knowing full well that the mother will do everything in her power to hinder the marriage. She does indeed force Trilby to give up Little Billee. Paradoxically, Little Billee's communication to his mother ensures that he retains the image of Trilby as an unattainable love object, thus enabling his growth as an artist. $^{1}$

In this fantasy, Slavoj Žižek (1994: 95) explains, sublimation relies on elevating a flesh-and-blood woman to an inaccessible, impossible object resisting symbolisation. This is the position of the cruel Lady familiar from courtly love. Little Billee's action is in keeping with what Žižek (1994: 96) calls "the paradox of the Lady": while ostensibly the masochistic lover desires intercourse, he actually wants obstacles in his way towards fulfilment. These obstacles ensure that he is arrested in a state of suspension and endless waiting. In the masochistic fantasy the cruel Lady functions as an object of desire that coincides with the force preventing its attainment (Žižek 1994: 96). While usually the symbolic father prohibits the son from pursuing the mother, now the mother assumes this function. Thus, instead of working through the oedipal prohibition, the masochistic lover resexualises it by positing woman as the seductive source of what du Maurier's narrator calls "the lordship of woman over all" (du Maurier 1998: 16). Associating the cruel Lady with the oedipal prohibition ensures that genital sexuality never takes place. Little Billee is a masochistic lover, for he turns the suspension of genital sexuality into the pleasure of being reborn as a true artist.

To reach the state of suspension, the masochist strikes a deal with the love object. This deal may even take the form of a private, written contract as in Leopold von Sacher-Masoch's works. George du Maurier's variation is to make the artist's mother strike this deal with Trilby: it is as if the first cruel Lady abdicated from her throne in favour of a second one. The women together ensure that Little Billee's love never reaches the genital stage. Although he suffers a breakdown, he nevertheless returns to England and begins to make himself a name as an artist. 
The significance that disavowal enjoys in the two types of lover's discourse under scrutiny here introduces differences between them. We just saw that the masochistic lover tries hard to make disavowal a permanent state of affairs. To be sure, the Barthesian lover also prizes those moments when the oedipal prohibition and the law are suspended, making the incestuous maternal cuddle with its endless talk possible. But he also prizes those moments when this prohibition and the law are intact, for they enable the actual sexual relationship. In one crucial aspect, however, these two discourses converge: disavowal suspends reality. For the Barthesian lover this suspension is what hinders his discourse from being affected by narrative movement based on plotting and change. It has this effect, because it ensures that the lover's discourse stays in a perpetual present. Without a past and a future a discourse cannot turn into a love story. The suspending role of disavowal that safeguards the present thus explains why intercourse may threaten the Barthesian lover's discourse. As we turn next to the larger social context in which love affairs take place, we gain insight into the threats that may crush this discourse and turn it into a familiar story of (unhappy) love.

\section{Show me whom to desire}

Lovers never have full control: the loved one may die, she may leave, or love may simply evaporate. Love relationships frequently lead to disappointment, tears, grief, and breakup. Thus, no matter what a lover does, outside forces may turn his discourse into a conventional love story with a beginning, middle, and an end. Barthes identifies the imitative nature of love as one factor causing breakups. He claims that no love is original: it always proceeds from other people, language, books, and so on. What this means is that "the loved being is desired because another or others have shown the subject that such a being is desirable" (Barthes 1978: 136). Every rival has first been a master or a guide, and this setup leads to difficulties. The lover says, "Just show me whom to desire, but then get out of the way!" (Barthes 1978: 137). The rival is, however, the one person with whom the lover can best talk about the loved object, because only the rival knows her unique merits. Trilby usefully illustrates this situation. When Trilby visits the artists' studio for the first time, both Little Billee and Svengali are 
present. Each man immediately notices her uniqueness: the artist sees her feet, while the musician hears her voice. The two men serve as mirrors for one another, each imitating the desire the other shows, although they choose different parts of Trilby's body as fetishes. ${ }^{2}$

Triangulation and rivalry provide further instructive points for comparison between the lover's discourse and the masochistic fantasy. Deleuze shows that the latter usually tests its strength through a triangular situation, because the presence of a rival, also interested in the love object, adds to the masochist's suspended, yet pleasurable pain. ${ }^{3}$ Svengali plays the part of this third wheel in Trilby, and I look briefly at what happens when he gets hold of her. Svengali represents yet another mode of a lover's discourse, namely, that of the demon lover bent on destroying the love object. Although Trilby is tone deaf, she has a magnificent voice and an unusually propitious physique for producing sounds. Svengali regards her as the voice he lacks. By mesmerising Trilby, Svengali is able to plant himself in her unconscious: "That Trilby was just a singing-machine [...] just the unconscious voice that Svengali sang with" (du Maurier 1998: 299).

2 Little Billee, Svengali, and Trilby are all depicted as internally divided figures. The artist's two names convey his double nature: he is Little Billee, a private man, and also William Bagot, a publicly displayed artist. This distinction is central to Trilby, because the artist is born through the private man's participation in the masochistic fantasy. Svengali, in turn, is a German Jew, a mixture of high artistic ambitions and vulgarity. As for Trilby, she is of EnglishScottish parentage, but has lived all her life in Paris. In light of Deleuze's analysis, one may say that her French side represents the South, associated with nature, passion, and heat, while her English side represents the North, associated with morality, restraint, and coldness. Little Billee prizes her Northern side. For him, Trilby must "take place as a picture," an event enabling him to put fantasy into pictures in the first place (see Stewart 1998: 77-78). This requirement reorganises Trilby's characteristics so that restraint prevails, while hinting at the existence of passion and ensuring that it never bursts through. She must embody an arrested state of the perpetual postponement of pleasure. In contrast, Svengali cultivates Trilby's Southern side: he dresses her up as a "Trilby of marble" (du Maurier 1998: 299), a classical statue, but the music he makes her perform draws on a wide register of feelings. Passion thus bursts through the classical attire. The rivals' contest over Trilby targets both the nature of the love object and its function as the springboard for art.

3 The rival plays a central role in the masochistic fantasy. Although this fantasy shoos away the Father's law, this law, of course, never disappears. The rival's presence suggests the possibility that the absent father may return. 
Under his tutelage, Trilby metamorphoses into La Svengali, a singing sensation. La Svengali performs clad in a classical robe with her bare, sandaled foot - the mark of her phallic nature - on a stool (du Maurier 1998: 209-210). Her triumph is vocalising Chopin's Impromptu. This piece confirms her standing as the cruel Lady elevated to the Thing, that is, as the object that cannot be integrated into the symbolic order, but that nevertheless resides in the subject as desire. On hearing her sing, Little Billee experiences "his old cosmic vision of the beauty and sadness of things, the very heart of them, and their pathetic evanescence," in short, "a glimpse behind the veil" (du Maurier 1998: 214). ${ }^{4}$ La Svengali's music revives Little Billee's ability to love by strengthening his subjection to her as his cruel Lady, but it also awakens his fierce jealousy of Svengali. What is most torturous for Little Billee is the thought that Svengali has turned Trilby into a perfect cruel Lady - a singing statue - the foundation of aesthetic creativity, while succeeding in having a sexual relationship with her. Svengali thus threatens to explode Little Billee's masochistic fantasy, but Svengali's sudden death postpones this event.

After the rival's demise, Little Billee takes Trilby under his protection. The now insane Trilby wastes away, growing "more beautiful in their eyes, in spite of her increasing pallor and emaciation - her skin was so pure and white and delicate, and the bones of her face so admirable!" (du Maurier 1998: 266). In a word, she has become a living statue. She is again Little Billee's cruel Lady - not Svengali's. ${ }^{5}$ It also appears as if pictorial art triumphs over music. This happiest phase in Little Billee's masochistic fantasy is shattered when Trilby receives an envelope containing Svengali's picture. Gazing at the picture is enough to mesmerise her, making her sing the Impromptu as never before. After the song ends, Trilby dies calling

4 Stewart (1998: 102) observes that music seeks to transcend word and meaning, and, in its climactic moments, verges on the cry. Thus, it may represent the moment when the human voice encounters the Real, that is, the realm of experience that cannot be symbolised.

5 Some critics such as Nina Auerbach (2000), Elaine Showalter (1995), and Mary Russo (1994) argue that as the novel's most powerful character, Trilby refuses to be contained by her two admirers. This impression, however, is an illusion that tallies with the masochistic fantasy. Thanks to the association of the cruel Lady with the Thing, Trilby must be larger than life. Yet the fact that Trilby has no real control over her fate - even what seems to be her free choice of leaving Little Billee has been manipulated by him - shows how restricted her role actually is. 
out Svengali's name. A doctor pronounces her dead, claiming that her death had actually taken place fifteen minutes before the performance. It thus seems that Svengali has managed to snatch her from beyond the veil. ${ }^{6}$ This event destroys Little Billee's fantasy, and he sees no way out for himself other than death. He soon dies, "as if he were starting on some distant holy quest, like some gallant knight of old [...] in another life" (du Maurier 1998: 288). The novel's narrator suggests that this artist's masochistic submission to a cruel Lady is so strong that the fantasy continues even in the afterlife.

Little Billee's choice of death ends his discourse as a lover; the novel recounts a full-fledged narrative with a beginning, middle, and an (unhappy) ending. Barthes points out that all possible solutions are internal to the amorous system. It is always the lover who goes away or dies; if he sees himself as departed or dead, what he sees is always a lover. This, Barthes maintains, is the trap of love: the lover is inside love's system without being able to substitute another system for it (Barthes 1978: 142-143). This trap introduces another important difference between a masochistic lover such as du Maurier's Little Billee and the lover in Barthes' A Lover's Discourse. The separating feature is this: the masochistic lover is not satisfied to let amorous madness cease of its own accord. He always pushes it to a violent crisis, which typically ends the love relationship and leaves him as the odd one out. In contrast, in the ideal case at least, the Barthesian lover knows that he cannot put an end to love's madness. What he can do, however, is to wait patiently for it to pass. The lover's lot is to let love's discourse run through him, raging at first, and then (perhaps) petering out of itself. This stance to love requires that the lover renounce his will to possess the other (Barthes 1978: 232-234). If, as was noted before, he has been within this discourse from birth onwards in the arms of his mother, then he can confidently submit himself to these fluctuating tides of love. ${ }^{7}$

6 Svengali's artistic vision is not masochistic. He never submits to Trilby in the same fashion as Little Billee does. He remains in charge, turning Trilby into a mechanical puppet.

7 Mavor (2007: 159) observes that Barthes wavers between being a smothering and a distanced lover, but she argues that he actually never really wanted to be the latter. 


\section{A lover's discourse versus a love story}

I would like to dwell further on Barthes' suggestion that a lover's discourse does not mix well with conventional love stories. On this point it is worth quoting him at some length:

The lover speaks in bundles of sentences but does not integrate these sentences [...] into a work; his is a horizontal discourse: no transcendence, no deliverance, no novel (though a great deal of the fictive). Every amorous episode can be, of course, endowed with a meaning: [...] it follows a path which is always possible to interpret according to a causality or finality [...]: this is the love story, subjugated to the great narrative Other, to that general opinion which disparages any excessive force and wants the subject himself to reduce the great imaginary current, the orderless, endless stream which is passing through him, to a painful, morbid crisis of which he must be cured, which he must get over. (Barthes 1978: 7)

The Barthesian lover is a vessel open to love's discourse. Unlike the masochistic lover, he renounces the will-to-possess, which is a further differentiating feature between them. This characterisation of the lover as an open vessel elucidates the non-narrative nature of his discourse. This discourse washes over him — or it courses through him — which means that it resembles more a tide than a narrative. Even if love ebbs, the wise lover knows that it will eventually flow again. Certainly, there is movement and thus change, but they are not narrative in kind. A lover's discourse is cyclical and repetitious rather than syntagmatically linear. The narrative pattern of a love story is stamped upon it afterwards, often under outside pressure, because the excessive, disorderly nature of this discourse makes it distasteful to others.

In order to elucidate further the relationship between a lover's discourse and love stories, it is helpful to view them in the light of Barthes's analysis of Sarrasine in $S / Z$. As is to be expected, the hermeneutic and proairetic codes (the codes of enigmas or secrets and action sequences respectively) provide the backbone of love stories, because together they organise the material into a plot. As we know, plots are processed in a linear fashion from a beginning to an end; they are thus non-reversible. In contrast, the semic code (thematic qualities associated with characters, places, and objects), the cultural code (various types of knowledge and wisdom), and the symbolic code in particular resist — or rather may be made to resist - 
recuperation into linear, non-reversible clusters of meaning. Barthes treats the various figures of the lover's discourse in a similar tabular, non-linear fashion as he deals with the narrative material he processes in terms of these three reversible codes. Consequently, he ensures the multivalent nature of these figures, fitting them to his notion of love as the realm of dreams and (pre-oedipal) fantasies. We may then conclude that discoursing as a Barthesian lover relies on the kind of construction that he illustrates in $S / Z$, one that disregards cohesion and unity, but keeps afloat multiple flickers of meaning (see Barthes 1974: 19-20, 151, 187-188, 214-217). Another way of putting this idea is to say that a Barthesian lover takes a writerly attitude to love.

Trilby is an instructive example in demonstrating how an author may contain the amorous excesses of his characters. The novel includes fragments of a lover's discourse, but they are controlled by being ordered as a love story. The novel accomplishes this control by separating the lovers from the narrator. In narratological terms, the narrator is extra- and homodiegetic; that is, he is part of the narrated world, but he does not participate in any of the events he recounts. He is an artist-writer, who has lived in Paris, frequenting the same circles as Little Billee. His position is that of a well-informed bystander. The random allusions to the narrator's biography suggest that he is a fictionalised version of George du Maurier himself, who is, as it were, doubly present in the novel through the roles of narrator and illustrator. The book includes numerous drawings of its main characters and key scenes by du Maurier. The feature uniting both narration and the illustrations is ironic distance. The narrator-illustrator's status as a bystander enables his wryly bemused comments about characters and events. From the fringes he looks into the teeming life of Bohemia. Mary Russo (1994: 130) remarks that by the late nineteenth century, Bohemia was a self-chosen subculture, a social and imaginative space where a young man could be an artist and live dangerously for a while. The narrator's distance from the world that is depicted is enhanced by his current status as someone who has settled for a bourgeois lifestyle, in a fashion similar to Little Billee's friend, the artist Taffy, at the novel's end. This social status is the best proof, of course, that neither Taffy nor the narrator was gifted enough to become a true artist - or a great lover.

Russo (1994: 140-141) draws attention to the grotesque discrepancy between the narrator's rapturous descriptions of Trilby's 
fetishistic foot, Little Billee's sketch of it, and du Maurier's two illustrations of this foot. The first illustration displays Little Billee sketching the foot without showing the result, while the second one depicts the sketch and Little Billee with his artist friends admiring it. In this latter illustration, the scrawny sketch is actually a grotesque caricature, neither a representation of the classic perfection of Nature nor a testimony to Little Billee's artistic gifts. What Russo does not consider, however, is that the illustration is not Little Billee's original sketch, but the narrator-illustrator's rendition of it. Readers access everything through him; consequently, neither Little Billee's art nor Svengali's music is directly available. The grotesque gap between his actual illustrations and the lofty things he says about art serve, I think, as George du Maurier's self-reflexive comment on his own artistry. This grotesque discrepancy is one of the ways in which the pseudobiographical narrator signals his recognition of his own artistic limits. He can write a best-seller and earn a good living as a caricaturist, yet he knows he will never reach the highest spheres of art. This awareness shapes his perspective: he remains an outsider both to the lover's discourse, the masochistic fantasy, and high artistic achievement. Although his narration is insulated against these discourses, they nevertheless reach readers through the fates of the male protagonists.

Throughout my essay I have deliberately treated the lover as a masculine subject. Given Barthes's goal of dramatising the structural site of a lover's discourse, his demonstration would ideally fit all lovers regardless of gender or sexual orientation. Yet Barthes's examples include only male lovers. Moreover, the figures that his lover's discourse shares with the masochistic fantasy further identify the lover as male. Mavor (2007: ch. 4) argues that the Barthesian lover's discourse is grounded in the special and limited case of Barthes's own life-long love for his mother, Henriette. Mavor (2007: 135) suggests that after Henriette's death, Barthes lost his will to live. In this reading then, Barthes's fate mirrors the destiny of the Barthesian lover - caught in the trap of love, the lover has only death as a way out. Barthes's biography may suggest as much, but Mavor's more significant observation concerns the Barthesian lover as "an eternal boy-child" (Mavor 2007: 143). Significantly, du Maurier

8 George du Maurier first recounted Trilby's plot to Henry James, asking the renowned author to turn it into a novel. James declined the offer, suggesting that du Maurier take up the task himself (Showalter 1995: x-xi). 
shares this characterisation of the lover by depicting Little Billee as a boy. Not only is Little Billee slender and slightly built, but also he is childlike and innocent. His boyishness emerges against the masculinity emphasised in his artist friends (Showalter 1995: xv). ${ }^{9}$ Thus, in Trilby too the male lover is markedly a boy. And to borrow Mavor's phrasing, the love of such boys "is ultimately an exaggerated, if obsessive, tug on the skirt of Maman" (Mavor 2007: 159).

The title of Barthes's probing of a lover's discourse, whether in French or in English, stresses the indefinite article (' $d$ ' $u n$ ' and 'a' respectively). It also emphasises the fragmentary character of this discourse. These are valuable clues to the nature of his undertaking, showing that the discourse he dramatises is not the one all lovers everywhere speak and write. It may be difficult, for example, for female lovers to identify fully with some of the figures Barthes discusses. Indeed, a closer look at Barthes's illustration of the workings of this discourse demonstrates its sexualised and genderbiased moorings. Moreover, reading A Lover's Discourse and Trilby side-by-side suggests that the Barthesian lover's discourse harkens back to nineteenth-century views about love, art, sublimation, and masculine lovers. It is this legacy that reverberates in the perceived hostility between love's discourse and love stories. A close reading of Barthes's book thus suggests the inevitable ties that any scrutiny of amorous discourse has with its historical contexts. It is truly fragmentary, as it carries echoes from many different sources. A Lover's Discourse opens up new avenues for future research: on the one hand, it encourages us to examine the links among gender, sexuality, and the particular ways in which lovers talk, write, and read; on the other hand, it promotes the study of the various discursive and narrative strategies with whose help we not only deal with the fascinating subject of love but also express it.

9 The narrator also mentions that Little Billee was "was especially in thrall to the contralto - the deep low voice that breaks and changes in the middle and soars all at once into a magnified angelic boy treble. It pierced through his ears to his heart, and stirred his very vitals" (du Maurier 1998: 43; italics added). The contralto merges a woman with a boy, and La Svengali is, of course, a contralto (du Maurier 1998: 209-210). 


\section{References}

Auerbach, Nina 2000. Daphne du Maurier: The Haunted Heiress. Philadelphia: University of Pennsylvania Press.

Barthes, Roland 1974. S/Z: An Essay. New York: The Noonday Press. [Translated by Richard Miller. Originally published as Barthes, Roland 1970. S/Z. Éditions du Seuil.]

- 1978. A Lover's Discourse: Fragments. New York: Hill and Wang. [Translated by Richard Howard. Originally published as Barthes, Roland 1977. Fragments d'un discours amoureux. Éditions de Seuil.]

Deleuze, Gilles 1989. Coldness and cruelty (Le froid et le cruel). In: Masochism. New York: Zone Books. [Originally published as Deleuze, Gilles 1967. Presentation de Sacher-Masoch. Éditions de Minuit.]

Fink, Bruce 1997. A Clinical Introduction to Lacanian Psychoanalysis: Theory and Technique. Cambridge: Harvard University Press.

Kolb, Katherine 2005. The tenor of 'Sarrasine'. PMLA 120(5): 1560-1575.

du Maurier, George 1998. Trilby. Oxford: Oxford University Press. [With an Introduction by Elaine Showalter and Notes by Dennis Denisoff. Originally published in 1894.]

Mavor, Carol 2007. Reading Boyishly: Roland Barthes, J. M. Barrie, Jacques Henri Lartigue, Marcel Proust, and D.W. Winnicott. Durham: Duke University Press.

Russo, Mary 1994. The Female Grotesque: Risk, Excess, Modernity. New York: Routledge.

Showalter, Elaine 1995. Introduction. In: du Maurier, George 1998, vii-xxi.

Stewart, Suzanne R. 1998. Sublime Surrender: Male Masochism at the Fin-deSiècle. Ithaca: Cornell University Press.

Ungar, Steven 1983. Roland Barthes: The Professor of Desire. Lincoln: University of Nebraska Press.

Žižek, Slavoj 1994. Courtly love, or, woman as thing. In: Žižek, Slavoj, Metastases of Enjoyment: Six Essays on Woman and Causality. London: Verso, 89-112.

\section{Как сохранять любовь: Ролан Барт, Джордж дю Морье и Жиль Делез}

В настоящей статье автор проводит сравнительный анализ «Дискурса влюбленных» (1977) Барта и «Трилби» (1894) дю Морье, высвечивая похожесть в их мазохистско-мужских фантазиях, как это явление теоретически описал Делез в своей книге «Холод и жестокость» (1989). Автор статьи исходит из убеждения Барта, что любовь и искусство связаны между собой. «Трилби» говорит о любви и 
эстетике в контексте искусства, музыки и нарратива. Речи соперничающих влюбленных, обращенные к одной женщине в «Трилби», являются основой сравнения с драматизацией речи влюбленного у Барта. По мнению автора статьи многие центральные фигуры речи влюбленного у Барта присущи и мазохистскому влюбленному Делеза. Рассматривая предположение Барта, что между ненарративным дискурсом любви и конвенциональными историями любви имеется определенное напряжение, и сосредотачиваясь на тех образах в речи влюбленного, которые по мнению Барта препятствуют ее становлению историей любви, автор утверждает, что некоторые из этих образов характерны для мазохистской фантазии. Более всего воспрепятствует превращению дискурса влюбленного в конвенциональный любовный нарратив формула отрицания.

\section{Kuidas armastust elus hoida: Roland Barthes, George du Maurier ja Gilles Deleuze}

Käesolev artikkel analüüsib võrdlevalt Barthes’i Armunu kõne (1977) ja du Maurier'i Trilby't (1894), paljastamaks sarnasusi nende mehelikmasohhistlikes fantaasiates, nagu seda nähtust on teoreetiliselt kirjeldanud Deleuze oma Külmuses ja Julmuses (1989). Artikli autori lähenemine lähtub Barthes'i veendumusest, et armastus ja kunst on seotud. Trilby räägib armastusest ja esteetikast kunsti, muusika ning narratiivi kontekstis. Rivaalitsevate armastajate kõned ühele ja samale naisele Trilby's ongi aluseks, millega võrdlen armastaja kõne dramatiseerimist Barthes'il. Väidan, et mitmed Barthes'i armastaja kesksed kõnefiguurid on omased ka Deleuze'i masohhistlikule armastajale. Vaatlen Barthes'i oletust, et mittenarratiivse armastuskõne ja konventsionaalsete armastuslugude metakeele vahel on teatud pinge ning keskendun neile kujunditele armunu kõnes, mis Barthes'i arvates takistavad sel muutumast armastuslooks. Väidan, et nii mõnedki neist kõnekujunditest on tunnuslikud masohhistlikule fantaasiale. Paremini kui miski muu, kaitseb armunu kõnet konventsionaalseks armastuse narratiiviks muutumise eest salgamise valem. 